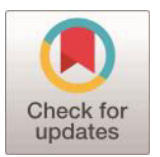

Article Type: Research Paper

\section{Analysis of COVID-19 Impact on Micro, Small, and Medium Enterprises (MSMEs) Credit Distribution in East Java Banks}

\author{
Evita Hayatun Nufus ${ }^{1}$, Idah Zuhroh ${ }^{1 *}$, and Muhammad Sri Wahyudi \\ Suliswanto $^{1}$
}

\begin{abstract}
:
Research aims: The purpose of this study was to determine the credit distribution level used as working capital assistance for Micro, Small, and Medium Enterprises (MSMEs) during the COVID-19 pandemic.

Design/Methodology/Approach: This study used a sample of 8 cities/regencies in East Java. Meanwhile, the Micro, Small, and Medium Enterprises (MSMEs) credit recipients were the population of the sample areas. This research's analysis model was panel data regression (generalized least square) by considering the emergence of heteroscedasticity in cross-section data between regional objects. The control variables outside the COVID-19 were the BI rate, third-party funds (TPF), and inflation.
\end{abstract}

*CORRESPONDENCE:

idahzuhro@umm.ac.id

THIS ARTICLE IS AVAILABLE IN: http://journal.umy.ac.id/index.php/ai

DOI: 10.18196/jai.v22i2.10701

\section{CITATION:}

Nufus, E.H., Zuhroh, I., \& Suliswanto, M.S.W. (2021). Analysis of COVID-19 Impact on Micro, Small, and Medium Enterprises (MSMEs) Credit Distribution in East Java Banks. Journal of Accounting and Investment, 22(2), 342-360.

\section{ARTICLE HISTORY}

Received:

29 Dec 2020

Revised:

13 Jan 2021

12 Feb 2021

Accepted:

04 Mar 2021
Research findings: This study's results showed that the COVID-19 pandemic had a significant negative impact only on medium-sized business loans, while micro and small business loans are more resilient. Besides, Micro, Small, and Medium Enterprises (MSMEs) credit was significantly positively influenced by TPF; inflation did not affect credit; the BI rate only negatively affected medium-sized business credit.

Theoretical contribution/Originality: Studies on Micro, Small, and Medium Enterprises (MSMEs) credit-related to economic phenomena and monetary policy have been widely carried out. However, the catastrophic virus that causes longterm economic uncertainty and impacts banks and Micro, Small, and Medium Enterprises (MSMEs) still requires in-depth study. Also, this study employed the GLS model that considers heteroscedasticity, which is still rarely used in previous studies.

Practitioner/Policy implication: This research can be essential information for the Indonesian Financial Services Authority (Otoritas Jasa Keuangan or OJK) and Bank Indonesia (BI) in policymaking, both regulatory aspects and bank liquidity provision, in stimulating Micro, Small, and Medium Enterprises (MSMEs) credit, especially in the COVID-19 pandemic era.

Research limitation/implication: The impact of COVID-19 on Micro, Small, and Medium Enterprises (MSMEs) loans is still classified based on micro, small and medium. It is still not grouped based on the Micro, Small, and Medium Enterprises (MSMEs) business sector in various cities and regencies in East Java. The analysis has not been clustered based on the spatial concentration of the Micro, Small, and Medium Enterprises (MSMEs) recipient areas. Keywords: MSMEs Credit; Third-Party Funds (TPF); BI Rate; Inflation; COVID-19; Investment 


\section{Introduction}

SARS-Cov-2, commonly known as COVID-19, is a virus caused by the severe acute respiratory syndrome coronavirus 2. Based on information from the COVID-19 task force, this virus has a swift spread rate. Apart from having an impact on decreasing the public health level, the COVID-19 pandemic has indirectly caused economic suffering around the world and a global economic downturn (Bartik, Bertrand, Cullen, Glaeser, Luca, \& Stanton, 2020; Disemadi \& Shaleh, 2020; Maital \& Barzani, 2020; McKibbin \& Fernando, 2020; Wyplosz, 2020). Declining demand, disruption of supply chains, cancellation of export orders, and lack of raw materials are examples of hampered economic activity due to the current COVID-19 virus outbreak (Shafi, Liu, \& Ren, 2020). Even the European Commission also stated that France and Italy are at risk of experiencing a recession due to the COVID-19 pandemic (Wyplosz, 2020). In Indonesia, one of the economic sectors identified as being affected by the COVID-19 pandemic is the Micro, Small and Medium Enterprises (MSMEs) sector due to the tendency to lack of business capital resulting from decreased income, which is in line with the current decline in people's purchasing power (Bahtiar \& Saragih, 2020; Nasution, Erlina, \& Muda, 2020; Pratiwi, 2020; Sarmigi, 2020; Thaha, 2020). The decrease in the level of people's purchasing power on MSMEs products is undoubtedly one of the main factors for MSMEs having difficulty earning income, which is also one of the main working capital for business actors to continue running their business (Nasution et al., 2020 Pakpahan, 2020; Sarmigi, 2020). The same thing also happen ed in Pakistan, where the COVID-19 pandemic has also resulted in MSMEs in Pakistan experiencing a decline in income (Shafi et al., 2020).

In Indonesia, it is estimated that around 1,785 cooperatives and 163,713 MSMEs experienced a decline in sales, lack of capital, and hampered distribution. The Ministry of Cooperatives and MSMEs reported that around 37,000 MSMEs stated that they were affected by the COVID-19 pandemic, marked by a 56 percent decline in sales, 22 percent difficulty in financing, 15 percent difficulty in distributing goods, and 4 percent difficulty in getting raw materials (Thaha, 2020). The decline in MSMEs capital also occurred in Pakistan, Europe, England, and India (Singh \& Bodla, 2020; Juergensen, Guimón, \& Narula, 2020; Albonico, Mladenov, \& Sharma, 2020; Shafi et al., 2020).

During a pandemic like this, the MSMEs sector really needs special attention from the government because this business sector is one of the largest contributors to domestic income and an economic sector with high employment (Bahtiar \& Saragih, 2020; Pratiwi, 2020). The Ministry of Cooperatives and Small and Medium Enterprises stated that MSMEs had difficulty obtaining capital to run businesses. Meanwhile, capital is significant for the sustainability of its business. Thus, with the lack of working capital, MSMEs overcomes this by making loans at banks, both at People's Credit Banks (BPR) or Conventional Banks.

Moreover, the decline in the existence and income of MSMEs during the pandemic has resulted in business actors experiencing difficulties in repaying loans according to maturity (Supeno \& Hendarsih, 2020). Based on the April 1 Press Conference, the 
Ministry of Finance stated that the result of MSMEs not running their businesses normally led to an increase in bad credit at MSMEs (Sihaloho, 2020). It can be said that this pandemic has also had an impact on the financial sector and banking performance in the field of crediting and financing in Indonesia due to disruption in the debtors' performance and capacity in carrying out credit payment obligations (Disemadi \& Shaleh, 2020). Besides, this pandemic will also reduce credit distribution to the public by banks (Supeno \& Hendarsih, 2020). The same thing happened to Indian banks that they had to reduce credit loans to business actors due to the government policy to lockdown during the COVID-19 pandemic (Singh \& Bodla, 2020). Moreover, in Turkey, the COVID19 pandemic has also impacted reducing credit claim rates (Zahariadis, Petridou, \& Oztig, 2020).

In the current pandemic situation, several banks have difficulty raising public funds (Singh \& Bodla, 2020; Ningsih \& Mahfudz, 2020). Meanwhile, the financing applied for business loans at banks cannot be separated from the collection of third-party funds (Widiyanti, Mariso, \& Sjahruddin, 2014). Collecting third-party funds (TPF) is one of the crucial activities in channeling credit used for the development of the business and investment world so that when people find it difficult to save, the business and investment world is difficult to develop (Parenrengi \& Hendratni, 2018). Also, banks distribute credit to the public to improve their standard of living and business actors to improve their capital system (Mulyati, 2017).

Besides impacting banks' difficulty in collecting third-party funds, the COVID-19 pandemic can also result in changes in a country's inflation rate (Meyer, Prescott, \& Sheng, 2020). Changes in the high inflation rate will certainly affect the level of bank loans to the public because it will decrease real interest rates, impacting decreasing the public's desire to raise funds in banks (Tika, 2015). Changes in inflation level can also affect BI's interest rate policy (Yodiatmaja, 2012). The BI interest rate is related to the inflation rate, namely the rate of decline and increase in the $\mathrm{BI}$ interest rate according to the inflation target rate (Haryanto \& Widyarti, 2017). The BI rate also has a relationship with bank lending because the $B \mathrm{~B}$ rate is an interest rate resulting from Bank Indonesia's policy, reflecting a country's monetary policy (Jayanti \& Deky, 2016). An increase in BI interest rates can affect an increase in loan interest rates, which will reduce public initiatives in borrowing funds from banks (Putra \& Rustariyuni, 2014).

Based on the description above, it can be said that COVID-19 impacts decreasing the MSMEs' income levels, which directly causes a decrease in the MSMEs' capital in Indonesia. Since the COVID-19 pandemic took place in Indonesia, more or fewer researchers have researched the impact of the COVID-19 pandemic on MSMEs players' capital growth (Amri, 2020; Bahtiar \& Saragih, 2020; Nasution et al., 2020; Pratiwi, 2020; Sarmigi, 2020). However, with the findings of various studies above, it still has not been found a study that investigated how the role of banks as credit lenders for MSMEs, which incidentally is one form of financial assistance provided by banks in terms of capital for MSMEs players. Research on bank credit performance during the COVID-19 pandemic states that credit growth is still occurring, but this growth has decreased before the COVID-19 pandemic (Supeno \& Hendarsih, 2020). Until now, specific research 
on how the development of credit distribution to MSMEs during the COVID-19 pandemic using quantitative analysis has not been found. Therefore, this study analyzed how Micro, Small and Medium Enterprises' capital system through credit distribution amid the COVID-19 pandemic. Specifically, this research investigated how the impact of COVID-19 on lending based on quantitative data to provide a detailed explanation of the impact of the COVID-19 pandemic on MSMEs credit distribution. This study took the population of credit distribution in East Java using a sample of data from 8 regencies in East Java, and the analysis in this study was carried out based on the scale of the credit distribution business: micro, small, and medium.

By conducting this research, the authors hope to provide views to policymakers, especially in the financial sector, regarding the importance of helping MSMEs capital survive amid the current pandemic. Apart from analyzing the impact of lending, it is essential to provide an overview of future research on how the COVID-19 pandemic affects bank lending. With the increasing number of researchers conducting research on MSMEs and credit during the COVID-19 pandemic, it is expected that many innovative solutions will emerge to help MSMEs in dealing with the difficulty of obtaining business capital amid the COVID-19 pandemic.

\section{Literature Review}

\section{Research on Economic Phenomena on Banking}

Economic phenomena that occur in the world will indirectly impact the Indonesian banking system's stability, as happened in 1998 in Indonesia (Oktavilia, 2008). The economic crisis phenomenon will lead to a banking financial crisis resulting from reduced financial liquidity (Sudarsono, 2009). It can also reduce bank lending expansion and an increase in the number of non-performing loans due to reduced profitability from the economic slowdown (Bollard, Hunt, \& Hodgetts, 2011). After the global economic crisis that occurred in 1997 and 2008, the current volume III crisis has occurred again due to the spread of COVID-19. The phenomenon of the COVID-19 pandemic has indirectly impacted the banking financial sector (Dermigug et al., 2011). It can be concluded that economic phenomena in various parts of the world will affect the banking financial sector, either directly or indirectly (Nugrahanti \& Novia, 2012; Seelye \& Ziegler, 2020).

\section{Role of Credit in Micro, Small, Medium Enterprises (MSMEs)}

Credit is all types of loans that must be returned or paid along with interest by the debtor or borrower to the creditor following the agreement agreed by both parties (Mulyati, 2017). Credit or financing for Micro, Small, and Medium Enterprises provides working capital and investment from banks to business actors (Hasanah \& Priantina, 2017). Besides, the Indonesian economy's resilience cannot be separated from the role of Micro, Small and Medium Enterprises, so that the role of banking is very much needed to assist MSMEs players in obtaining business capital through credit distribution 
(Khotimah \& Atiningsih, 2018). The term MSMEs credit distribution to banks is usually referred to as People's Business Credit (KUR) (Anggraini \& Nasution, 2013). As for the Regulation of the Minister of Finance Number 4/PMK/2015 concerning guidelines for the implementation of People's Business Credit states, the purpose of forming KUR is to create synergistic effectiveness and collaboration between business actors and government agencies/local government agencies (Azmi, 2016).

\section{The Effect of Third-Party Funds (TPF) on Credit Distribution of Micro, Small, and Medium Enterprises (MSMEs)}

In previous research (Febrianto \& Muid, 2013), it was revealed that third-party funds had a significant positive effect on credit distribution by commercial banks listed on the IDX 2009-2012. In research (Aldila, 2012), third-party funds (TPF) had a significant positive effect on MSMEs credit distribution to commercial banks in Indonesia. Thirdparty funds (TPF) are sources of funds collected by increasing public funds, including savings, current accounts, and deposits (Khotimah \& Atiningsih, 2018). Third-party funds (TPF) are the largest source of funds generated and relied on by every bank because they are funds raised from public funds and can reach $80-90 \%$ of managed funds (Febrianto \& Muid, 2013). If the level of collecting third-party funds (TPF) is higher, the bank can increase the amount of credit distribution (Sari, 2013). Basically, banking's main activity is collecting funds and channeling these funds back to the public in the form of credit.

$\boldsymbol{H}_{1}$ : Third-party funds (TPF) have a significant role in increasing credit distribution of Micro, Small, and Medium Enterprises (MSMEs).

\section{The Effect of Inflation on Credit Distribution of Micro, Small, and Medium Enterprises (MSMEs)}

The money demand theory by Keynes (Mankiw, 2003) states that the demand for cash will be used for transactions and precautionary motives depending on the amount of income. It is triggered that if the income increases, it will be in line with the amount of cash to be transacted and if it gets higher, it will lead to an increase in inflation (Perlambang, 2010). The increase in inflation will be overcome by a discounted monetary policy issued by Bank Indonesia (BI), namely increasing the interest rate on bank deposits to encourage people to save their money in banks and increasing the loan interest rates to reduce credit distribution to reduce the amount of money circulating in the community. Research by Hasanah and Priantina (2017) revealed that inflation positively affected MSMEs credit disbursement by commercial banks from 2007 to 2013. In further research by Tresnawati (2019), inflation positively and significantly affected the credit distribution of MSMEs in Islamic banks and sharia business units on Java island in 2010-2017.

Furthermore, inflation is an indicator of economic stability in a particular area (Central Statistics Agency/BPS). The general definition of inflation is the value at which the price 
level prevails in an economy (Ramandhana, Jayawarsa, \& Aziz, 2018). Thus, the inflation rate could significantly affect an item's production level. If the inflation rate is high, the public will usually withdraw the funds deposited in the bank. Then, it results in a decrease in bank income, which will later impact decreasing the bank lending level. Whereas if there is an increase in loan interest rates because of an increase in inflation, it can undoubtedly hinder banks from channeling credit.

$\boldsymbol{H}_{2}$ : Inflation has a significant role in decreasing credit distribution of Micro, Small, and Medium Enterprises (MSMEs).

\section{The Effect of BI Rate on Credit Distribution of Micro, Small, and Medium Enterprises (MSMEs)}

In Keynesian theory, the real sector economic activity will show the amount of aggregate expenditure, which will affect the determination of national income, while the function of interest rates in the real sector will trigger the balance of the goods market, where the equation forms the IS curve (Akhyar Syahnur, \& Asmawati, 2019). With the balance of the IS-LM curve because of the increase in money market interest rates controlled through Bank Indonesia (BI), it will trigger an increase and decrease in lending rates for lending to the real sector of MSMEs. In the research (Ichwani \& Dewi, 2018), there was an increase in MSMEs credit amount when the BI7Day Reverse Repo Rate was enacted. Therefore, this study suggested that Bank Indonesia focus more on determining BI \& Days REPO because of the policy. It affects the amount of MSMEs credit and is expected to increase the state treasury. Previous research by Wicaksana (2013) stated that the BI rate affected the amount of MSMEs credit disbursement to commercial banks operating in Indonesia for the period January 2011-May 2013. BI Rate is one of the policies issued by Bank Indonesia (BI) as a reflection of a monetary attitude or stance (Haryanto \& Widyarti, 2017). The BI Rate is a monetary operation whose efforts are made to manage liquidity on the money market to achieve monetary policy targets. The BI Rate can be used to determine the margin (difference) between the loan interest rate and the deposit interest rate. If there is an increase in loan interest rates, the credit level extended will be even lower.

$\boldsymbol{H}_{3}$ : $\mathrm{BI}$ Rate has a significant role in decreasing credit distribution of Micro, Small, and Medium Enterprises (MSMEs).

Based on the literature review, the authors briefly summarized the framework outline in this study, as shown in Figure 1. 


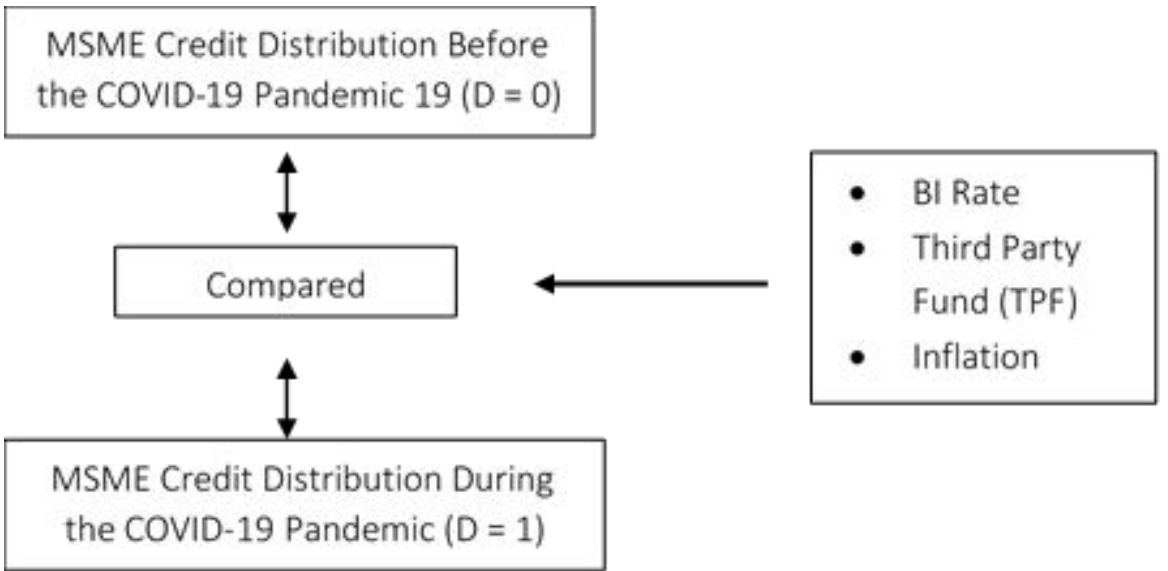

Figure 1 Conceptual Framework

\section{Research Method}

This study used quantitative data research with a variable relationship test approach. The type of data used in this research method itself was secondary data in quantitative. Secondary data was obtained from the BI SEKDA data source for the variable of credit distribution and third-party funds (TPF), the inflation data from the Central Statistics Agency (BPS), and the BI Rate data from the official website data bi.go.id. This study took a population in East Java Province; of 38 districts/cities, the authors used the purposive sampling method based on the survey results on the consumer price index (CPI) that the East Java Province government had determined. It was due to the inflation data's completeness and availability. Thus, the authors got a sample of 8 cities/districts in East Java to be research objects. The period of observation was 2018.01 to 2020.08 , and it involved 160 observations.

This study employed the effect test with the panel data regression method (pooled data) utilizing the EViews 2009 program, which would choose the best approach from the common effect, fixed effect, and random effect using a panel data regression test, namely the Chow test, Hausman test, and the Lagrange Multiplier Test. The best model selection only followed the Chow test criteria based on the common equation with the alternative hypothesis of the fix effect model at $\alpha=5 \%$. The next step was to test the classical assumptions in the form of non-heteroscedasticity and non-autocorrelation. Testing non-multicollinearity and normality is not required in panel data analysis (Kuncoro, 2012). If the panel data model contains heteroscedasticity without autocorrelation, it will be corrected by a cross-section weight. Conversely, if the model is exposed to autocorrelation and heteroscedasticity, it will be corrected by the SUR cross section model. The next step was to perform statistical tests both partially (t-test) and simultaneously ( $\mathrm{F}$ test) at $\alpha=5 \%$. This study investigated how much the independent variables' development and influence: third-party funds (TPF), Inflation, and BI Rate on the dependent variable: MSMEs credit distribution. 


\section{Nufus, Zuhroh, \& Suliswanto}

Analysis of COVID-19 Impact on Micro, Small, and Medium Enterprises (MSMEs) ...

This research had two research variables, namely the independent and the dependent variables. Detail about independent and dependent variables is presented in Table 1.

Table 1 Operational Definition of Variable

\begin{tabular}{|c|c|c|}
\hline Variable & Operational Definition & Indicator \\
\hline $\begin{array}{l}\text { Third-Party } \\
\text { Fund (TPF) }\end{array}$ & $\begin{array}{l}\text { Third-party fund (TPF) is one source of } \\
\text { funds collected by public funds } \\
\text { improvements (Khotimah \& Atiningsih, } \\
\text { 2018; Widiyanti et al., 2014). }\end{array}$ & $\begin{array}{l}\text { The total amount of third-party } \\
\text { funds (Giro, Time Deposit, Savings) } \\
\text { in all banks in } 8 \text { sample cities/ } \\
\text { regencies in East Java was } \\
\text { measured in millions of rupiahs. }\end{array}$ \\
\hline Inflation & $\begin{array}{l}\text { Inflation is a situation where the } \\
\text { tendency of an increase in the price } \\
\text { level is general and continuous (Tika, } \\
\text { 2015) }\end{array}$ & $\begin{array}{l}\text { The inflation rate in each sample of } \\
8 \text { cities/regencies in East Java was } \\
\text { measured in percentage units. }\end{array}$ \\
\hline BI Rate & $\begin{array}{l}\text { BI Rate is one of the government policies } \\
\text { issued by Bank Indonesia as one of the } \\
\text { monetary operations in managing } \\
\text { money market liquidity (Haryanto \& } \\
\text { Widyarti, 2017) }\end{array}$ & $\begin{array}{l}\text { The BI Rate was taken in the BI-7 } \\
\text { Day Reserve Repo Rate provisions, } \\
\text { measured in percent. }\end{array}$ \\
\hline $\begin{array}{l}\text { Credit Micro } \\
\text { Enterprises }\end{array}$ & $\begin{array}{l}\text { Micro enterprises are productive } \\
\text { businesses established by individuals } \\
\text { and/or business entities in accordance } \\
\text { with the criteria for micro-businesses } \\
\text { stipulated in Law Number } 20 \text { of } 2008 \\
\text { concerning Micro, Small and Medium } \\
\text { Enterprises (Tika, 2015) }\end{array}$ & $\begin{array}{l}\text { The amount of credit disbursed to } \\
\text { micro-entrepreneurs was in } \\
\text { accordance with the stipulated } \\
\text { business actor qualifications, } \\
\text { measured in millions of rupiahs. }\end{array}$ \\
\hline $\begin{array}{l}\text { Credit Small } \\
\text { Enterprises }\end{array}$ & $\begin{array}{l}\text { Small enterprises are productive } \\
\text { business groups that are independent or } \\
\text { established by business entities that are } \\
\text { not directly related to medium or large } \\
\text { businesses in accordance with the } \\
\text { criteria for small businesses stipulated in } \\
\text { Law Number } 20 \text { years } 2008 \text { concerning } \\
\text { Micro, Small and Medium Enterprises } \\
\text { (Tika, 2015) }\end{array}$ & $\begin{array}{l}\text { The amount of credit disbursed to } \\
\text { small business actors was in } \\
\text { accordance with the stipulated } \\
\text { business actor qualifications, } \\
\text { measured in units of millions of } \\
\text { rupiah. }\end{array}$ \\
\hline $\begin{array}{l}\text { Credit } \\
\text { Medium } \\
\text { Enterprises }\end{array}$ & $\begin{array}{l}\text { Medium enterprises are productive } \\
\text { business groups that are independent or } \\
\text { established by business entities that are } \\
\text { not directly related to small or large } \\
\text { businesses in accordance with the } \\
\text { criteria for small businesses stipulated in } \\
\text { Law Number } 20 \text { of } 2008 \text { about Micro, } \\
\text { Small and Medium Enterprises (Tika, } \\
\text { 2015) }\end{array}$ & $\begin{array}{l}\text { The amount of credit disbursed to } \\
\text { medium-sized business actors was } \\
\text { in accordance with the stipulated } \\
\text { business actor qualifications, } \\
\text { measured in units of millions of } \\
\text { rupiah. }\end{array}$ \\
\hline
\end{tabular}

The equation model is as follows:

$$
\begin{aligned}
& \operatorname{logKMik_{it}}=\alpha+\beta_{1} \log D P K_{i t}+\beta_{2} \operatorname{Inf}_{i t}+\beta_{3} B I R_{t}+D i+\varepsilon_{i t} \\
& \log K \operatorname{Mec}_{i t}=\alpha+\beta_{1} \log D P K_{i t}+\beta_{2} \ln f_{i t}+\beta_{3} B I R_{t}+D i+\varepsilon_{i t} \\
& \operatorname{logKMen_{it}}=\alpha+\beta_{1} \log D P K_{i t}+\beta_{2} \operatorname{In} f_{i t}+\beta_{3} B I R_{t}+D i+\varepsilon_{i t}
\end{aligned}
$$


From the three regression equations above, the impact of COVID-19 on MSMEs credit distribution was shown by the regression coefficient $\beta 4$. The COVID-19 event was proxied by the qualitative dummy variable (D), where the period before COVID-19 was before March $2020(D=0)$ and the COVID-19 period $(D=1)$ was March 2020 until the observation of August 2020. The dependent variable (KM, KK and KMen) was the amount of credit extended by banks in each district/city in East Java. In addition to the COVID-19 pandemic variable, the model included the variables of macroeconomic control and monetary policy in the form of inflation (Inf) and the benchmark interest rate (Birate), and bank-specific variables, namely third-party funds (TPF). All regression coefficients for the control variable can be interpreted as the elasticity of MSMEs lending. The COVID-19 pandemic shows a difference in MSMEs credit distribution before and during COVID-19 if $\beta 4$ is statistically significant at $\alpha=5 \%$.

The first-order test was in the form of statistical hypothesis testing for the COVID-19 (dummy) variable and control variables in accordance with the previous journal and empirical studies, revealing that COVID-19 had a negative effect on the MSMEs credit distribution. Control variables of Birate and inflation had a negative effect on MSMEs credit distribution. On the other hand, TPF had a positive effect on extending credit. Statistical testing concluded a significant influence between the dependent and independent variables by comparing the critical value ( $t$-table) and $t$ statistic. If $t$ stat $>t-$ table $(\alpha=5 \%)$, the null hypothesis is rejected, or the hypothesis statement related to the influence between the dependent and independent variables in the model can be accepted. The simultaneous test showing the F Stat> F table means that the model can explain the MSMEs credit changes well. The coefficient of determination (R2 adjusted) informs the model's ability to explain bank lending to MSMEs. The 22-panel data estimation model, the second-order test (test model selection and fulfillment of classical assumptions), and the first-order test (statistical test) utilized the EViews 9 software.

\section{Result and Discussion}

\section{Development of MSMEs Credit Distribution During the COVID-19 Pandemic}

The COVID-19 pandemic is one of the biggest challenges for Micro, Small and Medium Enterprises' sustainability. One of the efforts to support the existence of MSMEs in the community is tightening health protocols in carrying out economic activities for MSMEs, reducing grace periods for paying MSME's debt or credit and easing People's Business Credit (KUR) to maintain MSMEs financial liquidity (Pakpahan, 2020). 


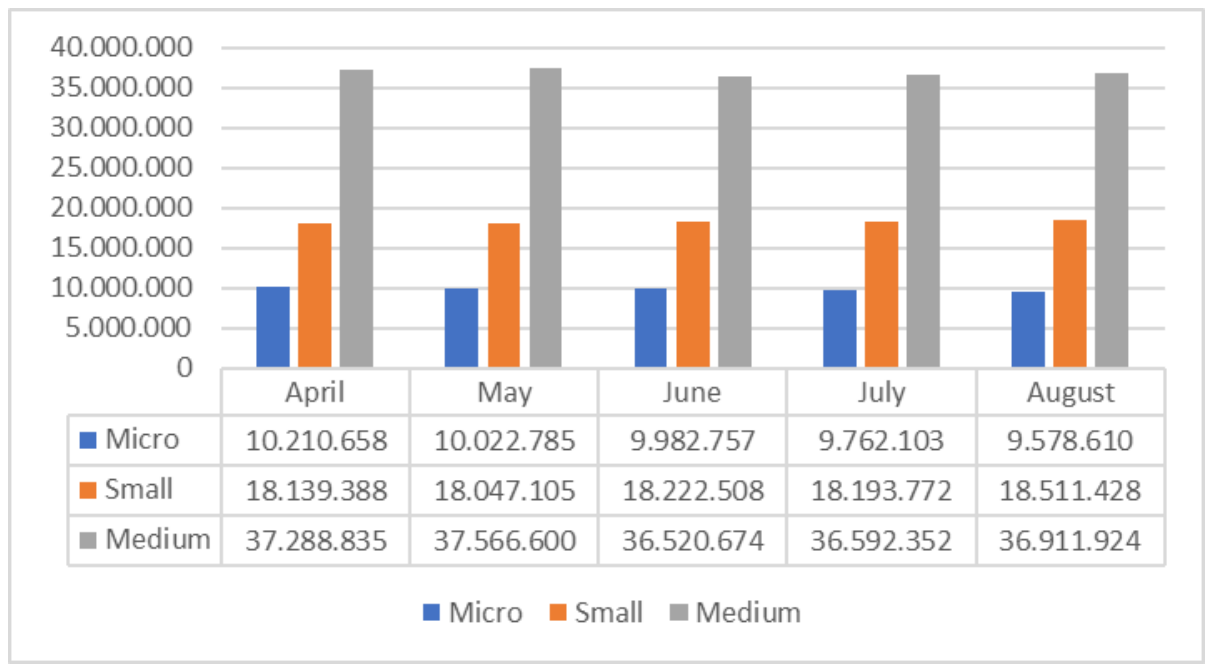

Figure 2 Levels of Credit Distribution for Micro, Small, and Medium Enterprises in 8 Cities/Regencies of East Java April-August 2020

Source: Development of MSMEs Credit in East Java (Processed by the author)

The figure of the development of Micro Business credit disbursement in 8 Cities/Regencies in East Java showed a decline from April to August 2020, to be exact, the first five months of COVID-19. However, the decline in the distribution of microbusiness loans was not that significant. Meanwhile, the figure above displays a stable graph, where the decrease and increase were not so significant from April to August 2020 in the first five months of COVID-19. In this case, it was mentioned that COVID-19 did not really impact lending to Micro, Small and Medium Enterprises in the first five months of the COVID-19 pandemic.

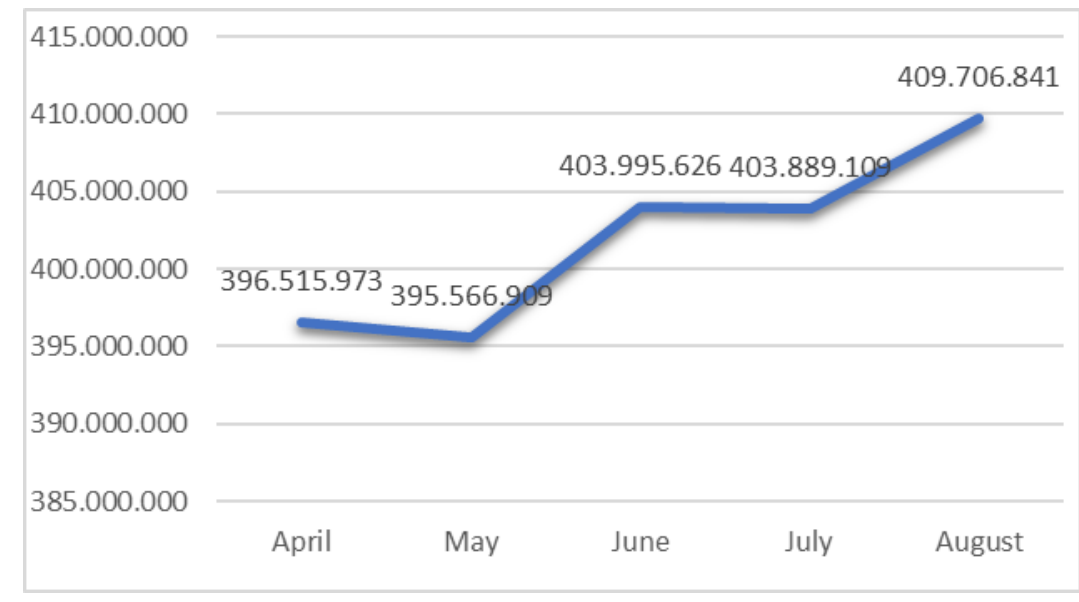

Figure 3 Levels of Collecting Third Party Funds Cities/Regencies of East Java April-August 2020 


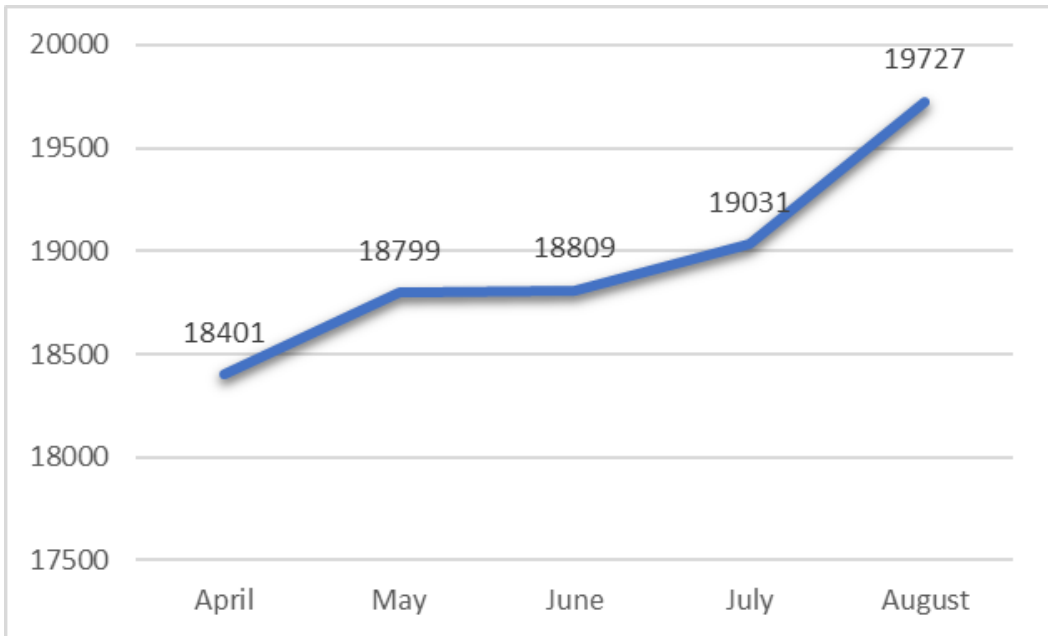

Figure 4 Non-Performing Loans in 8 Cities/Regencies of East Java April-August 2020 Source: Development of SPI TPF and NPL (Author processed)

At the beginning of the COVID-19 pandemic in Indonesia, banking indirectly hit Indonesia's banking sector, including East Java banking. Based on the graphic analysis above, it is found that Non-Performing Loans or non-performing loans in East Java banking have increased since April-August, but this has also been followed by the movement to raise the number of third-party funds, which has also increased.

So, it can be concluded that during the COVID-19 pandemic that occurred in East Java, the level of credit distribution continued to increase; this was also accompanied by an increase in the collection of third-party funds. However, this was also accompanied by an increase in non-performing loans as measured by the increase in non-performing loans since April-August.

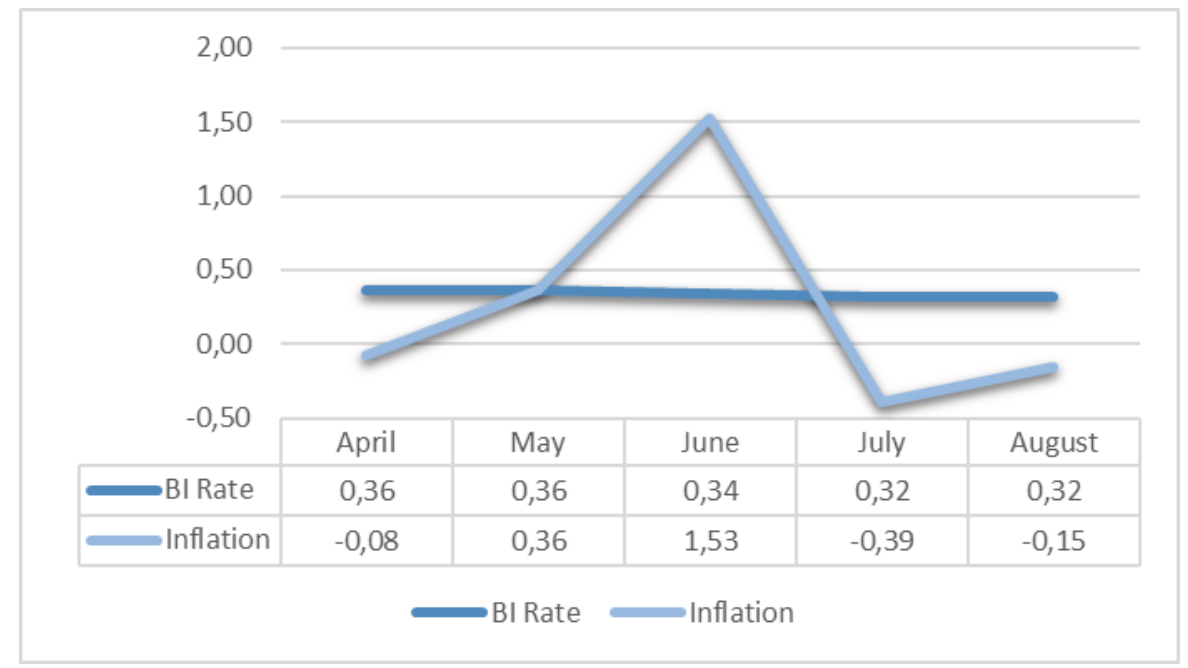

Figure 5 BI Rate and Inflation Data in 8 Cities/Regencies of East Java April-August 2020 Source: Development of the BI Rate and Inflation bi.go.id, Bps (Author processed) 
The analysis results showed that the $\mathrm{BI}$ Rate or $\mathrm{BI}$ benchmark interest rate obtained from the BI-7 Day Reserve Repo Rate data displayed a movement that could be said to be stable. With the reference interest rate's stability level, it was not surprising if the level of credit distribution in East Java during the COVID-19 pandemic did not experience a significant decline.

Furthermore, if looking at the macroeconomic variable, namely inflation, the data revealed that the inflation rate in 8 cities/regencies in East Java fluctuated; namely, a sharp increase in June, reaching $1.53 \%$, then dropping dramatically in July $-0.39 \%$. It could be said that the fluctuation of the initial inflationary movement was when the COVID-19 pandemic occurred and at the time the PSBB (large-scale social restrictions) in East Java was established. With the PSBB policy implemented in the first month of June, the community tended to be consumptive in basic supplies for quarantine so that it could trigger fluctuating movements in the inflation rate in East Java. However, the drastic increase and decrease did not really influence the level of bank lending. Hence, it could be inferred that the macro inflation variable had no significant effect on bank lending.

The analysis results of the effect of the independent variables (TPF, Inflation, BI Rate) on the dependent variable (credit distribution for Micro, Small, Medium Enterprises)

Details about the analysis result of the effect independent variables on dependent variables (credit distribution) for Micro, Small, and Medium Enterprises are exhibited in Table 2, Table 3, and Table 4.

Table 2 EViews Data Results Through Common Effect-Cross Section Weight Approach on Dependent Variable: Micro

\begin{tabular}{lccc}
\hline Variable & Coefficient & Probability & Description \\
\hline C & 5.354393 & 0.00000 & Significant \\
TPF & 0.486317 & 0.00000 & Significant \\
Inflation & -0.000131 & 0.99800 & Not Significant \\
BI Rate & 0.803253 & 0.68420 & Not Significant \\
Dummy & 0.076587 & 0.05240 & Not Significant \\
\hline
\end{tabular}

From the panel data regression analysis, the results exposed that the variable $\mathrm{C}$ (Micro Business) coefficient and the Third-Party Funds (TPF) variable showed a significant positive probability, meaning that it affected the distribution of micro-business loans. It supports previous research from Widiyanti et al. (2014), stating that TPF positively influenced Micro, Small, and Medium Enterprises (MSMEs) lending. The independent variable coefficient of inflation, $\mathrm{BI}$ rate, and dummy showed insignificant probability. It signified that the variables of inflation, the $\mathrm{BI}$ rate, and the dummy did not influence micro-business credit distribution.

Hence, it could be concluded that the hypothesis about the third-party fund was accepted, but the hypotheses of inflation and $\mathrm{BI}$ in the distribution of microloans in East Java banking were rejected. 
Nufus, Zuhroh, \& Suliswanto

Analysis of COVID-19 Impact on Micro, Small, and Medium Enterprises (MSMEs) ...

Table 3 EViews Data Results Through Common Effect-Cross Section Weight Approach on Dependent Variable: Small

\begin{tabular}{lccc}
\hline Variable & Coefficient & Probability & Description \\
\hline C & 3.852347 & 0.00000 & Significant \\
TPF & 0.612653 & 0.00000 & Significant \\
Inflation & 0.007094 & 0.80210 & Not Significant \\
BI Rate & 2.115154 & 0.03280 & Significant \\
Dummy & 0.035932 & 0.06980 & Not Significant \\
\hline
\end{tabular}

From the panel data regression analysis, the results disclosed that the variable C (Small Business) coefficient, the Third-Party Funds (TPF), and BI rate variables showed a significant positive probability, indicating that they affected small business credit distribution. It reinforces previous research (Hasanah \& Priantina, 2017; Khotimah \& Atiningsih, 2018; Mulyati, 2017), which found that TPF positively influenced MSMEs credit distribution. The independent variable of inflation's coefficient and the dummy variable showed insignificant probability. It denoted that the inflation and dummy variables did not affect the credit distribution to small businesses. This study's results support previous research (Pratiwi, 2019) that inflation had a positive but insignificant effect on MSMEs lending in Islamic Commercial Banks in Indonesia.

It can be then inferred that the third-party funds and BI Rate variables' hypothesis were accepted, yet the hypothesis concerning the inflation variable was rejected in the distribution of micro business credit in East Java banking.

Table 4 EViews Data Results Through Common Effect-Cross Section Weight Approach on Dependent Variable: Medium

\begin{tabular}{lccc}
\hline Variable & Coefficient & Probability & Description \\
\hline C & -2.088288 & 0.00000 & Significant \\
TPF & 0.98453 & 0.00000 & Significant \\
Inflation & 0.006728 & 0.74940 & Not Significant \\
BI Rate & -2.062784 & 0.00980 & Significant \\
Dummy & -0.100416 & 0.00000 & Significant \\
\hline
\end{tabular}

From the panel data regression analysis, results uncovered that the variable coefficient C (Small Business) showed a significant negative probability, affecting the credit distribution to medium-sized businesses. The independent variable coefficient of ThirdParty Funds (TPF) displayed a significant positive probability, and the BI Rate had a significant negative effect on the distribution of medium-sized business loans. It supports previous research by Puspita (2018), which stated that Third-Party Funds (TPF) had a significant effect on MSMEs credit distribution. Data of Indonesian conventional commercial banks and Ramandhana et al. (2018) revealed that the BI Rate had a significant negative effect on the distribution of People's Business Credit (KUR) to commercial banks in Indonesia for the period 2013-2017. Meanwhile, the independent variable coefficient of inflation showed a positive insignificant probability. It indicated that the inflation variable did not influence medium-sized business credit distribution. It corroborates with previous research by Husriah (2020) that inflation had no effect and was positive on MSMEs credit distribution at PT. Bank Perkreditan Rakyat (Persero) Tbk, 
Branch of Ahmad Yani Makasar. Meanwhile, the dummy variable had a negative effect on the credit distribution to medium enterprises.

It could be denoted that the variables of third-party funds and BI Rate supported the hypothesis, yet the inflation variable did not support the hypothesis in the distribution of micro business credit in East Java banking.

Based on the panel data regression analysis (generalized least square) by considering the emergence of heteroscedasticity in the cross-section data between the area objects above, it could be concluded that there were differences between the regression results of micro, small and medium enterprises. These differences could not be separated from the difference in the amount of bank credit distribution in the 8 sample cities/regencies because the differences based on this scale could represent the amount of credit extended by banks. Micro and small enterprises tend to get a smaller amount of credit disbursed than medium-sized businesses due to differences in capital requirements and differences in the amount of income that each business actor will receive based on the scale.

The results of the dummy variables for micro and small businesses stated that there was no influence on the credit distribution level in 8 cities/regencies in East Java after the COVID-19 pandemic for the first five months. The COVID-19 pandemic did not affect the level of credit disbursement to micro and small businesses with probability values of 0.05240 and 0.06980 . Inversely proportional to the distribution of medium business loans, the analysis results found that the COVID-19 pandemic had a negative effect on lending to medium-sized businesses with a probability value of 0.00000 and decreased credit disbursement of $-0.100416 \%$ every time the dummy variable value increased by $1 \%$.

The results did not affect the distribution of credit for micro and small businesses because, during the COVID-19 pandemic, the Ministry of Cooperatives and SMEs made special programs for MSMEs players, including:

1. The existence of restructuring and subsidies for micro-business credit interest rates

2. There was a special credit restructuring for cooperatives through LPDB KUMKM.

3. The micro sector, which is quite large in number and most vulnerable to COVID-19, received pre-employment cards for day laborers in the cluster.

Even so, the Financial Services Authority (OJK) revealed that it would reduce the impact of COVID-19 by employing the banking sector to facilitate credit payments for the micro, small and medium business sector (Bahtiar \& Saragih, 2020; Pratiwi, 2020).

The COVID-19 pandemic during April-August 2020 was identified as influencing the distribution of medium business loans. It could occur because medium-sized businesses had the highest levels of income, labor, and credit acceptance rates among micro and small businesses (Tika, 2015). Thus, medium-sized businesses were in the MSMEs group with many risks of being affected by the COVID-19 pandemic. 
In theory, the COVID-19 pandemic should be closely related to increasing inflation. Because when it is related to the Keynesian theory, if the amount of cash to be transacted is higher, an increase in inflation will occur (Perlambang, 2010). However, it contrasts with the direct events during the first five months of the COVID-19 pandemic, namely that there was no identified increase in inflation in East Java. Thus, it could be concluded that the COVID-19 pandemic did not have such a significant effect on increasing inflation in East Java. This study's results also supported that the inflation rate did not affect MSMEs credit distribution. It supports that inflation was not dangerous for the real sector of MSMEs, and Bank Indonesia did not issue a discount policy to overcome the money supply in society.

At the end of this study, it could be signified that the COVID-19 pandemic is a new noneconomic phenomenon that is indirectly related to changes in the economic system, both globally and regionally. New phenomena that impact the economy can also affect the country's financial system, including banking (Nugrahanti \& Novia, 2012; Seelye \& Ziegler, 2020). It is what can explain the identification of COVID-19, which impacts credit distribution, especially credit to MSMEs. The economic crisis phenomenon will affect the level of financial liquidity, leading to a reduction in credit expansion by financial parties and can increase the risk of non-performing loans (Bollard et al., 2011; Sudarsono, 2009). Moreover, the new phenomenon of the COVID-19 pandemic is currently very challenging for micro, small, and medium business actors. Thus, this identification is robust, and it has been proven that COVID-19 has impacted reducing the credit distribution level to MSMEs business actors at the medium scale business.

\section{Conclusion}

Based on the research results and discussion, it could be concluded that regarding the distribution of micro and small business credit, the COVID-19 pandemic did not affect increasing or decreasing credit distribution in 8 cities/regencies in East Java. It was displayed from the probability results of the dummy variables of 0.05240 and 0.06980 . Meanwhile, the distribution of medium-sized business loans showed that the COVID-19 pandemic had a negative effect on the credit distribution level to medium-sized businesses. It was shown by the probability of a dummy variable of 0.00000 , with a variable coefficient of -0.100416 . Thus, if there were an increase in the dummy variable by $1 \%$, there would be a decrease in credit distribution by $-0.100416 \%$ in 8 cities/regencies of East Java when the COVID-19 pandemic occurred.

Based on the results and conclusions above, the authors suggest that the government should strive to help micro, small, and medium-sized businesses in stimulating credit distribution because medium-sized businesses are also among the businesses most affected by the current COVID-19 pandemic. The government must be able to issue policies that can support MSMEs businesses during the COVID-19 pandemic.

This research was conducted using only the first five months of data during the COVID19 pandemic by only looking at the credit distribution based on a business scale. 
Therefore, it needs to be studied further on the impact of COVID-19 on MSMEs credit distribution. This study can be used as a reference for future academics and researchers, with the hope of researching MSMEs credit distribution based on the business sector, business capital, and investment capital during the COVID-19 pandemic to help MSMEs in getting working capital to run their businesses amid this COVID-19 pandemic. Besides, it can be carried out for the sustainability of MSMEs to become one of the economic sectors ready to respond to various economic shocks in the future.

\section{References}

Akhyar, M., Syahnur, S., \& Asmawati, A. (2019). Analisis interaksi kebijakan fiskal dan moneter terhadap perekonomian Indonesia. Jurnal Perspektif Ekonomi Darussalam, 5(2), 112-123. https://doi.org/10.24815/jped.v5i2.15080

Albonico, M., Mladenov, Z., \& Sharma, R. (2020). How the COVID-19 crisis is affecting UK small and medium size enterprises. Retrieved from https://www.mckinsey.com/industries/public-and-social-sector/our-insights/howthe-covid-19-crisis-is-affecting-uk-small-and-medium-size-enterprises

Aldila, G. F. (2012). Analisis pengaruh dana pihak ketiga, tingkat suku bunga, dan non performing loan terhadap penyaluran kredit UMKM pada bank umum di Indonesia. Jurnal Ekonomi Pembangunan, 10(1), 81. https:// doi.org/10.22219/jep.v10i1.3719

Amri, A. (2020). Dampak COVID-19 terhadap UMKM di Indonesia. Jurnal Brand, 2(1), 147153. Retrieved from https:// ejournals.umma.ac.id/index.php/brand/article/view/605

Anggraini, D., \& Nasution, S. (2013). Peranan Kredit Usaha Rakyat (KUR) bagi pengembangan UMKM di kota Medan (Studi Kasus Bank BRI). Jurnal Ekonomi Dan Keuangan, 1(3).

Azmi, N. (2016). Peranan kredit usaha rakyat untuk pengembangan UMKM. Undergraduate Thesis. Universitas Islam Indonesia.

Bahtiar, R.A., \& Saragih, J.P. (2020). Dampak COVID-19 terhadap perlambatan ekonomi sektor UMKM . Info Singkat, 7(0), 19-24. Retrieved from https://berkas.dpr.go.id/puslit/files/info singkat/Info\%20Singkat-XII-6-II-P3DIMaret-2020-1982.pdf

Bartik, A. W., Bertrand, M., Cullen, Z., Glaeser, E. L., Luca, M., \& Stanton, C. (2020). The impact of COVID-19 on small business outcomes and expectations. Proceedings of the National Academy of Sciences, 117(30), 17656-17666. https://doi.org/10.1073/pnas.2006991117

Bollard, A., Hunt, C., \& Hodgetts, B. (2011). The role of banks in the economy-improving the performance of the New Zealand banking system after the global financial crisis. BIS Central Bankers' Speeches. Retrieved from https://www.bis.org/review/r110810b.pdf

Disemadi, H. S., \& Shaleh, A. I. (2020). Banking credit restructuring policy amid COVID-19 pandemic in Indonesia. Jurnal Inovasi Ekonomi, 5(2), 63-70. https://doi.org/10.22219/jiko.v5i3.11790

Febrianto, D. F., \& Muid, D. (2013). Analisis pengaruh dana pihak ketiga, LDR, NPL, CAR, ROA, dan BOPO terhadap jumlah penyaluran kredit (Studi pada bank umum yang terdaftar di Bursa Efek Indonesia periode tahun 2009-2012). Diponegoro Journal of Accounting, 2(4), 259-269. Retrieved from https:// ejournal3.undip.ac.id/index.php/accounting/article/view/5921 
Haryanto, S. B., \& Widyarti, E. T. (2017). Analisis pengaruh NIM, NPL, BOPO, BI Rate dan CAR terhadap penyaluran kredit bank umum go public periode tahun 2012-2016. Diponegoro Journal of Management, 6(4), 942=952. Retrieved from https:// ejournal3.undip.ac.id/index.php/djom/article/view/18062

Hasanah, N., \& Priantina, Y. (2017). Pengaruh tingkat suku bunga, inflasi dan rasio kecukupan modal terhadap penyaluran kredit UMKM oleh bank umum di Indonesia tahun 2007-2013. Jurnal Informasi Akuntansi dan Keuangan (INFAK), 3(2), 106-113. Retrieved from http://jurnal.poliupg.ac.id/index.php/infak/article/view/179

Ichwani, T., \& Dewi, R. S. (2018). Pengaruh perubahan BI rate menjadi BI 7 day reverse repo rate terhadap jumlah kredit UMKM. Jurnal Manajemen dan Bisnis, 1(1), 67-76. Retrieved from https://journal.moestopo.ac.id/index.php/jmb/article/view/1337

Jayanti, S., \& Deky, D. (2016). Pengaruh inflasi dan BI rate terhadap pembiayaan usaha mikro kecil dan menengah (Studi kasus pada bank umum Syariah). I-Economics: $A$ Research Journal on Islamic Economics, 2(2), 86-105. Retrieved from http://jurnal.radenfatah.ac.id/index.php/ieconomics/article/view/1026

Juergensen, J., Guimón, J., \& Narula, R. (2020). European SMEs amidst the COVID-19 crisis: Assessing impact and policy responses. Journal of Industrial and Business Economics, 47(3), 499-510. https://doi.org/10.1007/s40812-020-00169-4

Khotimah, F. Q., \& Atiningsih, S. (2018). Pengaruh DPK, NPL, LDR dan suku bunga kredit terhadap penyaluran kredit UMKM (Studi pada BPR di kota Semarang tahun 20132016). Jurnal STIE Semarang, 10(2), 42-57. https://doi.org/10.33747//stiesmg.v10i2.198

Maital, S. \& Barzani, E. (2020). The global economic impact of COVID-19: A summary of research Haifa Israel: Samuel Neaman Institute. Retrieved from https://www.neaman.org.il/EN/The-Global-Economic-Impact-of-COVID-19-ASummary-of-Research

McKibbin, W. J., \& Fernando, R. (2020). The global macroeconomic impacts of COVID-19: Seven scenarios. SSRN Electronic Joumal. https://doi.org/10.2139/ssrn.3547729

Meyer, B. H., Prescott, B., \& Sheng, X. S. (2020). The Impact of the COVID-19 Pandemic on Business Expectations. SSRN Electronic Journal. https://doi.org/10.2139/ssrn.3690489

Mulyati, S. (2017). Pengaruh Dana Pihak Ketiga (DPK), Non Performing Loan (NPL) dan Loan to Deposito Ratio (LDR) terhadap penyaluran kredit periode 2013-2016 (Pada PT. Bank Perkreditan Rakyat di Kabupaten Bima). Undergraduate Thesis. Fakultas Ekonomi Dan Bisnis Islam UIN Alauddin Makassar.

Nasution, D. A. D., Erlina, E., \& Muda, I. (2020). Dampak pandemi COVID-19 terhadap perekonomian Indonesia. Jurnal Benefita, 5(2), 212-224. https://doi.org/10.22216/jbe.v5i2.5313

Ningsih, M. R., \& Mahfudz, M. S. (2020). Dampak pandemi COVID-19 terhadap manajemen industri perbankan syariah: Analisis komparatif. Point, 2(1), 1-10. https://doi.org/10.46918/point.v2i1.576

Nugrahanti, Y. W., \& Novia, S. (2012). Mekanisme corporate governance terhadap kinerja perbankan. Jurnal Manajemen, 11(2), 151-170.

Oktavilia, S. (2008). Deteksi dini krisis perbankan Indonesia: Identifikasi variabel makro dengan model logit. Jejak: Jurnal Ekonomi dan Kebijakan, 1(1), 1-14. Retrieved from https://journal.unnes.ac.id/nju/index.php/jejak/article/view/1448

Pakpahan, A. K. (2020). COVID-19 dan implikasi bagi usaha mikro, kecil, dan menengah. Jurnal Ilmiah Hubungan Internasional, 59-64. Retrieved from https://journal.unpar.ac.id/index.php/JurnalIlmiahHubunganInternasiona/article/vie $\mathrm{w} / 3870$ 
Parenrengi, S., \& Hendratni, T. W. (2018). Pengaruh dana pihak ketiga, kecukupan modal dan penyaluran kredit terhadap profitabilitas bank. Jumal Manajemen Strategi dan Aplikasi Bisnis, 1(1), 9-18. https://doi.org/10.36407/imsab.v1i1.15

Perlambang, H. (2017). Analisis pengaruh jumlah uang beredar, suku bunga SBI, nilai tukar terhadap tingkat inflasi. Media Ekonomi, 18(2), 49-69.

https://doi.org/10.25105/me.v18i2.2251

Pratiwi, M.I. (2020). Dampak COVID-19 terhadap perlambatan ekonomi sektor UMKM. Jurnal Ners, 4(2), 30-39.

https://journal.universitaspahlawan.ac.id/index.php/ners/article/view/1023

Putra, I. G. O. P., \& Rustariyuni, S. D. (2014). Pengaruh DPK, BI Rate, dan NPL terhadap penyaluran kredit modal kerja pada BPR di Provinsi Bali Tahun 2009-2014. E-Jurnal Ekonomi Pembangunan Universitas Udayana, 4(5), 451-464. Retrieved from https:// ojs.unud.ac.id/index.php/eep/article/view/12129

Ramandhana, D. Y., Jayawarsa, A. A. K., \& Aziz, I. S. A. (2018). Pengaruh inflasi, suku bunga BI rate, pertumbuhan ekonomi, Non Performing Loan (NPL) dan Capital Adequa- cy Ratio (CAR) terhadap penyaluran Kredit Usaha Rakyat (KUR) pada bank umum di Indonesia Periode 2013-2017. Warmeda Economic Development Journal, 1(1), 3040. Retrieved from https://www.ejournal.warmadewa.ac.id/index.php/wedj/article/view/1117

Sari, G.N. (2013). Faktor-faktor yang mempengaruhi penyaluran kredit bank umum di Indonesia (Periode 2008.1 - 2012.2). Jurnal Riset Ekonomi, Manajemen, Bisnis dan Akuntansi, 1(3), 931-941. Retrieved from https://ejournal.unsrat.ac.id/index.php/emba/article/view/2298

Sarmigi, E. (2020). Analisis pengaruh Covid-19 terhadap perkembangan UMKM di Kabupaten Kerinci. Al Drabab Islamic Economy Journal, 1(1), 1-17. Retrieved from http://scholar.google.com/scholar?cluster=11657954505854208290\&hl=en\&oi=sch olarr

Seelye, N., \& Ziegler, P. (2020). Impacts of COVID-19 on banking. SSRN Electronic Journal. https://doi.org/10.2139/ssrn.3645556

Shafi, M., Liu, J., \& Ren, W. (2020). Impact of COVID-19 pandemic on micro, small, and medium-sized Enterprises operating in Pakistan. Research in Globalization, 2. https://doi.org/10.1016/j.resglo.2020.100018

Sihaloho, E. D. (2020). Dampak COVID-19 terhadap perekonomian Indonesia. https://doi.org/10.31219/osf.io/h2d7c

Singh, J. \& Bodla, B.S. (2020). COVID-19 pandemic and lockdown impact on India's banking sector: Asystemic literature review. In Raj Pal Singh, Anupama Singh and Rakesh Kumar, COVID-19 Pandemic: A Global Challenge, 21-32.

Sudarsono, H. (2009). Dampak krisis keuangan global terhadap perbankan di Indonesia: perbandingan antara bank konvensional dan bank syariah. La_Riba, 3(1), 12-23. https://doi.org/10.20885/lariba.vol3.iss1.art2

Supeno, W., \& Hendarsih, I. (2020). Kinerja kredit terhadap profitabilitas BPR pada masa pandemi COVID-19. Jurnal Akrab Juara, 5(4), 147-161. Retrieved from http://akrabjuara.com/index.php/akrabjuara/article/view/1290

Thaha, A. F. (2020). Dampak COVID-19 terhadap UMKM di Indonesia. Jurnal Brand, 2(1), 147-153. Retrieved from https://ejournals.umma.ac.id/index.php/brand/article/view/ 607

Tika, R. M. (2015). Pengaruh CAR, LDR, NPL, tingkat inflasi, dan kebijakan perubahan aturan definisi UMKM terhadap share penyaluran kredit UMKM oleh perbankan di Indonesia. Jurnal Ilmiah Mahasiswa Fakultas Ekonomi dan Bisnis, 3(2). Retrieved from https://jimfeb.ub.ac.id/index.php/jimfeb/article/view/1864 


\section{Nufus, Zuhroh, \& Suliswanto}

Analysis of COVID-19 Impact on Micro, Small, and Medium Enterprises (MSMEs) ...

Tresnawati, L. (2019). Pengaruh DPK, NPF dan inflasi terhadap pembiayaan syariah sektor UMKM pada bank syariah dan unit usaha syariah di pulau jawa tahun 2010-2017. Undergraduate Thesis. Universitas Islam Indonesia.

Wicaksana, M. B. P. (2013). Pengaruh faktor kinerja bank dan BI rate terhadap jumlah penyaluran kredit usaha mikro kecil dan menengah. Undergraduate Thesis. Universitas Bakrie.

Widiyanti, W., Mariso, M., \& Sjahruddin, S. (2014). Analisis Pengaruh CAR, ROA, NPL, BOPO, dan DPK terhadap penyaluran kredit UMKM di Indonesia. Jurnal Online Mahasiswa Fakultas Ekonomi, 1(2).

Wyplosz, C. (2020). Economics in the time of COVID-19. CEPR Press

Yodiatmaja, B. (2012). Hubungan antara BI rate dan inflasi pendekatan kausalitas Toda Yamamoto. Jejak: Jurnal Ekonomi dan Kebijakan, 5(2).

https://journal.unnes.ac.id/nju/index.php/jejak/article/view/3902

Zahariadis, N., Petridou, E., \& Oztig, L. I. (2020). Claiming credit and avoiding blame: political accountability in Greek and Turkish responses to the COVID-19 crisis. European Policy Analysis, 6(2), 159-169. https://doi.org/10.1002/epa2.1089 